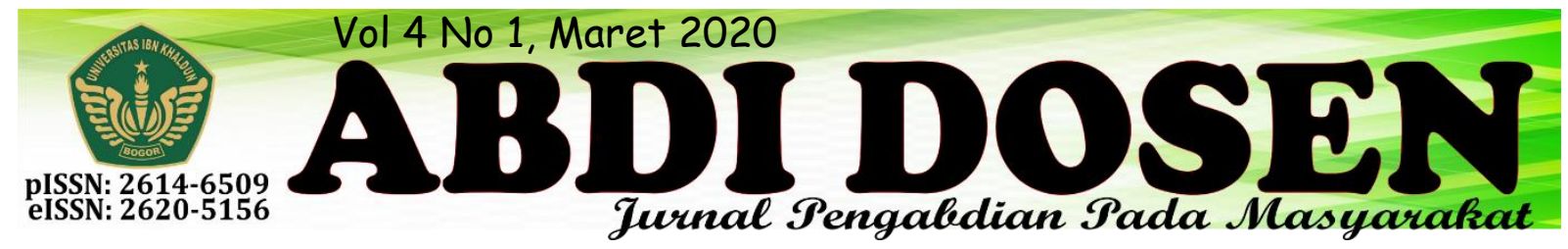

\title{
MENINGKATKAN KUALITAS MUTU MASYARAKAT BERBASIS TEKNOLOGI, BERBAHASA DAN BERAGAMA DEMI MENUNJANG DESA PARIWISATA YANG LEBIH PRODUKTIF
}

\author{
Maemunah Sa'adiyah ${ }^{1}$, Alan Jaelani ${ }^{2}$, Raden Muhammad Jiddan Aziz, Yola Maulida ${ }^{3}$ \\ maemunah@fai.uika-bogor.ac.id ${ }^{1}$ \\ alan.jaelani@uika-bogor.ac.id ${ }^{2}$
}

Dosen Fakultas Agama Islam¹, Dosen Fakultas Ilmu Pendidikan², Mahasiswa KKN kelompok 15\&16 Tahun $2019^{3}$

\begin{abstract}
ABSTRAK
Sebagai salah satu bentuk daripada Tri Dharma Perguruan Tinggi, Kuliah Kerja Nyata Tematik Terintegrasi merupakan orientasiprogram yang kegiatannya terfokus pada bidang tertentu sesuai dengan permasalahan kemasyarakatan dan arah kebijakan pembangunan yang diselenggarakan pemerintah wilayah tertentu, adapun Kuliah Kerja Nyata Bertujuan untuk mencapai ekselerasi dan efektivitas program kerja pembangunan yang ditandai dengan semakin baiknya kualitas kehidupan masyarakat dan program program pembangunan. Beberapa tahap yang dilakukan dalam melakukan penelitian dan proses mengabdi ketika berlangsung dengan bermodalkan Data dan Hasil Survey yang telah dilakukan dari tanggal 6 Agustus hingga 6 September di Desa Pabangbon maka dari itu memutuskan mengunggulkan infrastruktur terutama teknologi dalam menunjang desa pariwisata yang tak luput dari Pengajaran Keagamaan dan Berbahasa Internasional. Tidak lupa Program Kerja dalam membantu masyarakat lainnya yang telah dilakukan seperti: Membuat Seminar Pendidikan Kepada Guru dan Wali Murid, Mengajar PAUD (Pendidikan Anak Usia Dini), Mengajar Diniyah, Tahsin Al-Quran, Pengajian Ratib Al-Hadad, Majelis Talim dan Doa Bersama, Pawai Obor, Tabligh Akbar, Senam Sehat, PHBS (Penyuluhan Perilaku Hidup Bersih dan Sehat) sekaligus renovasi MCK (Mandi Cuci Kakus), Penyuluhan dan Simulasi Evakuasi Gempa, Gemar Menabung Sejak Dini, Pelatihan Kewirausahaan (Produk dan Pemasaran), Seminar Pasar Modal Syariah, Kursus Komputer, Penerangan Jalan Umum berbasis Tenaga Surya, Perayaan 17 Agustus Sedesa dan Sekampung, Nobar (Nonton Bareng) Film Perjuangan, Gapura Masjid, Bakti Sosial, Kerja Bakti, Penyuluhan Hukum perkawinan dan Hukum tanah dalam aspek perdata dan pidana. Pada intinya semua Program Kerja dapat terealisasi karena ada dorongan doa dan usaha terutama Masyarakat di dalamnya, semoga apa yang telah di abdikan dapat dirasakan langsung oleh masyarakat.
\end{abstract}

\section{Keyword : Kuliah Kerja Nyata, Masyarakat, Program Kerja}

\section{PENDAHULUAN}

Kuliah Kerja Nyata (KKN) adalah suatu bentuk pendidikan dengan cara memberikan pengalaman belajar kepada mahasiswa untuk hidup ditengah - tengah masyarakat, secara terstruktur melalui beberapa tahap diantaranya persiapan, pembekalan, observasi sampai tahap evaluasi. Sebagaiman pengertian dari 
Kuliah Kerja Nyata (KKN) Tematik Terintegrasi adalah KKN yang orientasi program terfokus pada bidang tertentu sesuai dengan permasalahan kemasyarakatan dan arah kebijakan pembangunan yang diselengarakan pemerintah pada Wilayah tertentu (Kabupaten/Kota). Dengan demikian bahwa KKN Tematik Terintegrasi berbasis problem solving untuk memecahkan masalah dengan tema tertentu sehingga kegiatan mahasiswa terfokus untuk mengatasi masalah tertentu sehingga kegiatan mahasiswa terfokus untuk mengatasi masalah tertentu dan untuk mencapai target tertentu sesuai dengan permasalahan.

Pembangunan di Indonesia ditujukan ke semua bidang, tidak terkecuali bidang kesehatan, pendidikan, ekonomi, kelembagaan, dan pemberdayaan lingkungan. Hal ini belum mampu dipenuhi oleh pemerinta secara optimal, dikarenakan kurangnya keikutsertaan fungsi keluarga sebagai pendidikan dasar bagi masing-masing individu. Pembangunan pada lima bidang tadi sangat berpengaruh dalam membangun masyarakat Indonesia.. Peran serta dari berbagai pihak sangat dibutuhkan untuk membangun dan mengembangkan kelima bidang tersebut, oleh pihak akademisi termasuk mahasiswa.

Universitas Ibn Khaldun Bogor (UIKA) sebagai salah satu lembaga pendidikan yang berada di kawasanKotaBogor memiliki kewajiban untuk berperan serta secara aktif dalam pembangunan dibidang kelembagaan, kesehatan, pendidikan, ekonomi serta pemberdayaan lingkungan. Peran tersebut bukan hanya dilakukan oleh mahasiswanya saja, namun oleh masyarakat di sekitar kampus dan masyarakat luas. Salah satu bentuk peran aktif tersebut adalah dengan diadakannya Kuliah Kerja Nyata (KKN) Tematik Terintegrasi yang diselenggarakan oleh Lembaga Penelitian dan Pengabdian. Kecamatan Leuwilliang sebagai salah satu kecamatan di Kabupaten Bogor dengan luas wilayah (-+) 94,01 km² yang terdiri dari 13 Desa, dengan jumlah penduduk pada tahun 2019 adalah 122.352 Jiwa. Secara demografis memiliki banyak potensi, diantaranya bidang pariwisata, perkebunan, dan kewirausahaan yang dapat dioptimalkan dalam usaha untuk pembangunan Desa serta meningkatkan perekonomian masyarakat Desa tersebut. Namun, pada kenyataannya yang diperoleh di lapangan berbagai potensi tersebut selama ini belum dapat dioptimalkan dengan baik oleh masyarakat sekitar. Untuk mendukung hal tersebut, perlu juga dilakukan peningkatan di bidang kesehatan dan pendidikan sebagai dasar terbentuknya sumber daya manusia yang berpotensi agar terciptanya sumber daya masyarakat yang lebih baik.

Desa Pabangbon merupakan bagian dari Kecamatan Leuwilliang dimana Desa Pabangbon memiliki luas wilayah 1.197 Hektar dan memiliki 13 RW dan beberapa Kampung, khususnya di Kampung Cilame II memiliki sektor pertanian yang cukup luas, Kampung Cilame II berada di RW 07. Pelaksanaan Kuliah Kerja Nyata (KKN) Tematik Terintegrasi dinilai karena pembangunan bidang kelembagaan sepertibidang kesehatan, pendidikan, ekonomi serta pemberdayaan lingkungan di kawasan tersebut belum optimal.

Berdasarkan permasalahan di atas, dilaksanakanlah program oleh tim Kuliah 
Kerja Nyata (KKN) Pemberdayaan dan Pengembangan Masyarakat Desa Pabangbon Kecamatan Leuwilliang Kabupaten Bogor sebagai salah satu

\section{METODE PENGABDIAN}

Dalam melaksanakan penelitian ini, kami menggunakan metode field research atau penelitian lapangan yaitu penelitian yang dilakukan langsung ke lapangan yaitu ke desa pabangbon untuk mengetahui secara langsung kondisi masyarajat setempat.

Adapun Metodepengabdian lain yang digunakan dalam kegiatan ini adalah:

1. Pendekatan religius, yaitu pendekatanyang menggunakan nilainilai agama sebagai basis kegiatan. Pendekatan ini sangat penting karna umumnya Masyarakat Desa Pabangbon memiliki pemahaman Agama yang sangat baik (Rachmawati, 2010).

2. Pendekatan kekerabatan, artinya bahwa pembinaan yang dilakukan senantiasa dikaitkan dalam rangka membangun kekerabatanan tarjama'ah yang semakin memudar. Nurhayati (2005) Menemukan bahwa faktor pendukung toleransi umat Islam dengan Hindu adalah adanya sistem kekerabatan. masyarakat pabangbon khususnya Kp. Cilame II memiliki kekerabatan yang sangat erta, sehingga para mahasiswa sangat mudah diterima oleh masyarakat setempat. upaya untuk mengoptimalkan fungsi keluarga sebagai anggota masyarakat.

3. Pendekatan berdasarkan karakter masyarakat, yakni pembinaan yang dilakukan akan disesuaikan dengan karakter masyarakat. Joyce dan Weil (1996) mengungkapkan bahwa model pendidikan yang relevan dengan perilaku sosial dan Nilai adalah dengan banyak memberikan permainan peran. Hal inidilakukan untuk memberi pengalaman riil kepada peserta didik tentang sesuatu yang dilakukan atau dirasakan oleh orang lain. Bahkan dalam prakteknya, tidak seluruh aspek harus menggunakan permainan ini. Dalam beberapa hal, terdapat kegiatankegiatan yang hanya golongan tertentu untuk melakukannya.Sejalan dengan konsep Joyce dan Weil, cooperative learning yang digagas Slavin (2005) dapat digunakan untuk membangun kesadaran toleransi masyarakat. Hal ini karena penekanan dari konsep pendidikan ini adalah kerja sama yang merupakan urat nadi toleransi. Dengan demikian, model pendidikan yang akan dibangun menggunakan dua konsep utama yaitu role playing model dan cooperative learning model. 


\section{REALISASI KEGIATAN}

1. Time Line Kegiatan

\begin{tabular}{|c|c|c|c|c|c|}
\hline \multirow{2}{*}{ No. } & \multirow{2}{*}{ Nama Kegiatan } & \multicolumn{4}{|c|}{ Minggu } \\
\hline & & 1 & 2 & 3 & 4 \\
\hline \multicolumn{6}{|c|}{ Pendidikan } \\
\hline 1. & $\begin{array}{l}\text { Pelaksanaan Kurikulum } 2013 \text { (K-13) } \\
\text { di SDN }\end{array}$ & & & & \\
\hline 2. & Mengajar PAUD & & & & \\
\hline 3. & Mengajar Diniyah & & & & \\
\hline 4. & 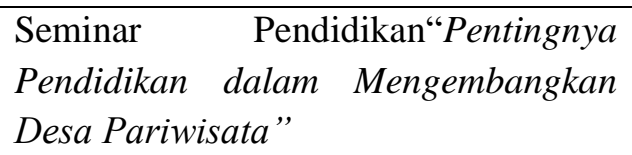 & & & & \\
\hline 5. & Cinema Class & & & & \\
\hline \multicolumn{6}{|c|}{ Keagamaan } \\
\hline 6. & Tahsin Al-Quran & & & & \\
\hline 7. & Ratib Al-Haddad & & & & \\
\hline 8. & $\begin{array}{l}\text { Majelis Talim dan Do'a bersama } \\
\text { Malam jum'at }\end{array}$ & & & & \\
\hline 9. & Pawai Obor Kp cilame (PHBI) & & & & \\
\hline 10. & $\begin{array}{l}\text { Pawai dan Tabligh Akbar desa } \\
\text { Pabangbon (PHBI) }\end{array}$ & & & & \\
\hline \multicolumn{6}{|c|}{ Kesehatan Masyarakat } \\
\hline 11. & Senam Sehat & & & & \\
\hline 12. & $\begin{array}{l}\text { Penyuluhan Perilaku Hidup Bersih dan } \\
\text { Sehat }\end{array}$ & & & & \\
\hline 13. & Simulasi Evakuasi Gempa Bumi & & & & \\
\hline \multicolumn{6}{|c|}{ Ekonomi } \\
\hline 14. & Gemar Menabung Usia Dini & & & & \\
\hline 15. & Pelatihan Kewirausahaan & & & & \\
\hline 16. & Seminar Pasar Modal Syariah & & & & \\
\hline \multicolumn{6}{|c|}{ Teknik } \\
\hline 17. & Kursus Komputer & & & & \\
\hline 18. & Nonton film bareng & & & & \\
\hline 19. & Renovasi (MCK) Mandi, Cuci, Kakus & & & & \\
\hline 20. & Pemasangan Lampu Penerangan & & & & \\
\hline 21. & Pembuatan Gapura Masjid & & & & \\
\hline
\end{tabular}

\section{Program Kerja Divisi Pendidikan}

a. SeminarPendidikan "Pentingnya Pendidikan Teknologi dalam Mengembangkan Desa Pariwisata" Dalam menunjang minat tingkat wisatawan kedalam desa pabangbon selaku generasi muda wajib dibekali berbahasa yang benar dan bahasa inggris untuk menghadapi turis manca negara, bukan hanya itu penting juga bagi kami untuk memberikan edukasi terhadap para orang tua/wali murid SDN Sinar Karya Baru agar menyadarkan para orang tua dan guru-guru akan pentingnya pendidikan agar siap menghadapi revolusi industri 4.0. Hal ini pun berguna untuk bisa 
memberikan edukasi terkait mengembangkan pariwisata yang ada di desa tersebut, pelaksanaannya pada tanggal 20 Agustus 2019 Pukul 08:00 - Selesai.

b. Pelaksanaan Kurikulum 2013 (K-13) di SD Kurikulum 2013 atau yang biasa disebut K-13 adalah kurikulum yang berlaku dalam Sistem Pendidikan Indonesia. Kurikulum ini merupakan kurikulum tetap diterapkan oleh pemerintah untuk menggantikan Kurikulum 2006 (KTSP). Di SDN Sinar Karya Baru baru menerapkan K-13 pada tahun ajaran 2019/2020 secara full sebagai kurikulum yang berlaku untuk saat ini, sehingga sekolah tersebut masih membutuhkan pengetahuan dan pengalaman baru mengenai K-13 ini terlebih kepada guru-guru SDN Sinar Karya Baru. Kedatangan pengawas pada sekolah tersebut pun menjadi salah satu alasan program ini dilakukan. Belum terlaksananya Active Learning adalah tujuan program ini di buat. Active Learningmenjadikan siswa lebih aktif di kelas, karena pusat belajar tidak berada di pihak guru melainkan berada di siswa itu sendiri, menjadikan siswa lebih percaya diri dalam menyampaikan pendapatnya,pelaksanaannya setiap Hari Rabu dan Kamis rutin jam 08:00 - Selesai.

c. Mengajar PAUD, Melihat minimnya tenaga pengajar di wilayah kp Cilame 2 terutama dalam guru PAUD maka dari itu team dari pendidikan merambah masuk membantu dalam pengajaran PAUD terutama di PAUD Putra Raksa IV, tujuannya agar dapat membantu menilai potensi murid, mengasah pemikiran, menemukan bakat dan lainnya, agenda ini rutin di laksanakan pada hari Senin dan Rabu pada pukul 08.00-09.00 WIB

d. Mengajar Madrasah Diniyah adalah salah satu lembaga non formal yang mengajarkan tentang nilai-nilai keislaman. Nilai-nilai keIslaman itu tertuang dalam bidamg studi seperti adanya pelajaran Fiqh, Aqidah Akhlak, Al-Qur'an dan Hadist, dan pelajaran lainnya. Madrasah Diniyah memiliki peran penting untuk mengajarkan nilai-nilai Islam yang lebih mendalam. Sama hal nya dengan yang lain, tenaga pengajar yang kurang lagi lagi membuat hati bergerak untuk membantu dalam halpengajaran, ditambah beberapa pelajaran yang tertinggal maka dari itu manfaat dan tujuan nya sangat jelas beberapa pelajaran K13 di terapkan untuk memajukan Madrasah Diniyah disana, adapun waktu kegiatan : Disetiap hari Senin, Kamis dan Jumat pukul 13.00-Selesai

\section{Program Kerja Divisi Agama}

a. Tahsin Al-Qur'an, "Perumpamaan orang mukmin yang membaca Alquran adalah seperti bunga utrujjah, baunya harum dan rasanya lezat. Sebaliknya orang mukmin yang tidak suka membaca Alquran adalah seperti buah korma, baunya tak begitu harum, tetapi manis rasanya. Sedangkan orang munafik yang membaca Alquran ibarat sekuntum bunga, berbau harum tapi pahit rasanya dan orang munafik yang tidak membaca Al-Qur'an tak ubahnya laksana buah hanzalah, tidak berbau dan rasanya pahit sekali." (HR Bukhari dan Muslim). Maka dari itu tujuan dari Tahsin Qur'an 
yaitu Meningkatkan, memperbaiki dan membenarkan bacaan Qur'an pada anak anak, desa pabangbon dengan waktu pelaksanaan setiap hari Ba'da Magrib.

b. Pengajian Ratib Al-Haddad, Ratib Al-Haddad dan juga Ratib Al-Attas yang merupakan susunan kalimatkalimat dzikir ini, tak diragukanl agi keutaman-keutamannya. Dalam suatu riwayat, tidak ada sebuah rumah yang dibacakan Ratib Al-Haddad pada malam hari, terkecuali Allah S.W.T menjaga rumah tersebut dari segala bahaya, hingga malam berikutnya. Tujuannya Meningkatkan ketenangan Jiwa Masyarakat Pabangbon Dengan Dzikir dan Memakmurkan Masjid At-Takwa Kp Cilame II Desa Pabangbon, dengan waktu pelaksanaan di minggu ke 2 dan 3 Bada Isya - Selesai.

c. Majlis Ta'lim, Tujuan Majlis ta'limadalah membina dan mengembangkan hubungan yang santun dan sesuai atau serasi antara manusia dengan Allah, antara manusia dengan manusia lainnya, antara manusia dengan tempat tinggal sekitarnya atau lingkungan, dalam rangka meningkatkan ketaqwaan mereka kepada Allah S.W.T terutama terhadap Kampung Cilame II dengan mayoritas tingkat keagamaannya tinggi maka dari itu dengan adanya wadah senantiasa terjaga Tujuan umum suatu Majlis Ta'lim adalah membina dan mengembangkan hubungan yang santun dan serasi antara manusisa dengan Allah, sesama manusia, dan lingkungannya dalam membina masyarakat yang bertaqwa kepada Allah SWT. Sedangkan tujuan khusus dari majlis ta'lim adalah memasyarakatkan ajaran islam.Waktu pelaksanaan untuk Ikhwan setiap malam jumat Ba'da Isya, dan untuk akhwat di hari jumat pagi pukul 08.00 - Selesai

d. Pawai Obor, Tujuan dan manfaatnya menjadikan ajang silaturahmi sekaligus memperingati Hari Besar Islam 1 Muharram dengan menggandeng para santri sekaligus generasi muda dalam mempererat kebersamaan serta meraih kedamaian menyambut perayaan Hari Besar Islam, kegiatan ini diadakan se- Kp Cilame II Desa Pabangbon tanggal 31 Agustus Pukul 20.00 WIB Selesai

e. Pawai dan Tabligh Akbar, Hampir sama dengan yang sebelumnya, namun memperbesa rwilayah menjadi sedesa pabangbon untuk merasakan kebersamaan serta merayakan haribesar islam, tak luput memperkuat keimanan dengan mendengarkan beberapa mubalighsampai kan. Di adakan se Desa Pabangbon Tanggal 03 September 2019 pukul 08.00WIBSelesai.

\section{Divisi Kesehatan Masyarakat}

a. Senam Sehat adalah suatu kegiatan olah raga jasmani yang dilakukan dalam durasi waktu 30 menit dengan cara menggerakkan seluruh anggota tubuh secara teratur yang dilakukan sebanyak 10 macam gerakan. Kegiatan ini merupakan salah satu pengabdian yang dapat saya lakukan didalam rangkaian program $\mathrm{KKN}$. Melakukan kegiatan yang bermanfaat bagi masyarakat yang tinggal di Kp Cilame II menjadi tujuan utama dilakukannya program. Senam ini di 
lakukan di Kp Cilame II Desa Pabangbon Kecamatan Leuwiliang. Dan kemudian KKN 15 \& 16 juga mengadakan senam sehat yang di ikuti oleh seluruh warga masyarakat Kp Cilame II. Persiapan senam sehat yang akan dilakukan dibantu oleh semua anggota kelompok KKN 15 \& 16, kami mulai mempersiapkan pembuatan surat undangan, penyebaran undangan, pamflet, teknis dan tempat pelaksanaanya. Setelah senam sehat kami membagikan snack untuk warga $\mathrm{Kp}$ Cilame II dan bersama - sama membersihkan tempat pelaksanaan dengan semua anggota kelompok.Tujuan dari kegiatan senam sehat adalah agar masyarakat Kp. Cilame II terhindar dari penyakit yang disebabkan oleh gaya hidup yang tidak sehat karena kurangnya aktivitas olahraga. Hambatan/ Kekurangan Lokasi yang kurang memadai untuk melakukan kegiatan senam sehat, dengan Realisasi Program kerja di Hari Minggu Tanggal25 Agustus 2019T empat Jalan Perbatasan Kp. Cilame II Pukul 15.40 WIB - Selesai

b. Penyuluhan PHBS ( Perilaku Hidup Bersih Sehat )

PHBS merupakan singkatan dari Pola Hidup Bersih dan Sehat. Adapun pengertian dari PHBS adalah sekumpulan perilaku hidup yang dipraktekkan oleh masyarakat yang dapat meningkatkan kesehatandiri dan lingkungan disekitar tempat tinggal masyarakat tersebut. Dalam pelaksanaan kegiatan KKN, program penyuluhan PHBS dilakukan di lingkungan sekolah dasar mengingat masih banyak anak-anak yang belum mengetahui tentang perilaku PHBS yang sangat penting dipraktekkan dalam kehidupan sehari-hari terutama di lingkungan sekolah. Kesadaran akan pentingnya tempat bersuci sebenarnya telahmelekat pada pemahaman setiap insan, semua sadar bahwa kenyamanan dalam melaksanakan ibadah diantaranya apabila rukundan syaratnya terpenuhi. Bersuci merupakan bagian dari yang dimaksud. Namun demikian keinginan dan harapan ini harus ditundaseiring dengan kondisi kemampuan yang tidak seluruhnya memiliki kelebihan materi. Alhasil dana yang terhimpun belum mampumewujudkan sarana kebersihan yang diharapkan. Lingkungan sehat adalah harapan seluruh manusia, budaya bersih adalah salah satu faktor utama untuk mewujudkan lingkungan sehat. Seluruh masyarakat sudah menyadari akan pentingnya kesehatan, karena itulah di Kp Cilame II Desa Pabangbon. Sarana yang terdapat Kp. Cilame II Desa Pabangbon merupakan salah satu sarana yang benar-benar dibutuhkan untuk mewujudkan lingkungan sehat. Tujuan dari kegiatan Penyuluhan PHBS (Perilaku Hidup Bersih Sehat) untuk memperluas tentang pentingnya mencuci tangan yang benar. Pelaksanaan PHBS di hari Rabu pukul 08.00 - selesai di SDN Sinar Karya Baru dan Lingkungan Kp.Cilame II Desa Pabangbon.

c. Simulasi Evakuasi Gempa Bumi

Bencana adalah peristiwa atau rangkaian peristiwa yang mengancam dan mengganggu kehidupan dan 
penghidupan masyarakat yang disebabkan baik factor alam maupun faktor non alam,maupun faktor manusia ,sehingga mengakibatkan timbulnya korban jiwa manusia, kerusakan lingkungan, kerugian harta benda,dan dampak psikologi. (Suratman Woro Suprojo, Prosiding pengindraan jauh dan system informasi geografi.2012). Tujuan dari kegiatan simulasi evakuasi gempa bumi untuk memperluas pengetahuan cara evakuasi saat terjadi gempa Pelaksanaan di HariRabu, Tanggal 28 Agustus 2019, Tempat/Sasaran SD Karya Baru, Pukul 08.00 WIB - Selesai

\section{Program Kerja Bidang Ekonomi}

a. Menabung Sejak Dini

Dibawah ini merupakan tujuan dari menabung antara lain ialah sebagai berikut : Mengajarkan menghemat pengeluaran supaya hidup tidak boros kepada siswa Paud Reksa Putra, Mengajarkan mengatur keuangan dengan baik, Mengajarkan Merencanakan serta mempersiapkan hari kedepan. Menyukseskan pembangunan kegiatan terealisasi di hari Rabu tanggal 21 Agustus 2019 Pukul 08.00WIB-Selesai di Paud Raksa Putra IV.

b. Pelatihan kewirausahaan

Dengan adanya berbagai sumberdaya alam di dalamnya, terutama pada kacang tanah, kolangkaling, singkong dsb. Maka dari itu atas permintaan dan potensi yang ada membuat pelatihan kewirausahaan membuat peyek sekaligus beberapa penyuluhan yang di berikan kepada ibu-ibu Kp. Cilame II mengenai produk, proses, menghitung anggaran penjualan, strategi marketing modern dengan mendobrak beberapa pasar terutama di area wisata Pabangbon, tujuannyayaitu menambah daya ekonomi masyarakat dan potensi, terealisasi anggaran pada hari Sabtu tanggal 24 Agustus 2019 di jam 09.00 - Selesai di rumah wargasetempat.

c. Seminar Pasar Modal, Adapun tujuan dari pembentukan pasar modal. Mengumpulkan kesempatan pada masyarakat Sekecamatan Leuwiliang untuk meningkatkan suatu pertumbuhan ekonomi. Memberikan kesempatan pada masyarakat untuk ikut memiliki perusahaan dan ikut menikmati hasilnya (laba), adapun tujuan yang akan di kejar dalam seminar ini dengan pengecualian yang pengasilannya mampu di atas rata-rata memberi pemahaman perputaran uang. Pelaksanaannya pada hari Rabu Tanggal 21 Agustus 2019 pukul 08.00 WIB-Selesai.

\section{Program Kerja Divisi Teknik}

a. Kursus Komputer, diartikan sebagai pembelajaran terhadap siswa/pun remaja putus sekolah agar tidak tertinggal oleh zaman memperkenalkan bagian serta isi dalam komputer salah satunya Microsoft dan tools yang ada di Laptop/Komputer.Direalisasikan setiap Malam dipukul 20.00-Selesai, lokasi nya berada di Posko KKN

b. Nonton Film Bareng di Cilame II, Edukasi dan meresapi nilai perjuangan para pahlawan di hari 17 Agustus untuk mencapai kemerdekaan terutama memotivasi pemuda yang ada di wilayah $\mathrm{Kp}$. Cilame II menjaga keutuhan berbangsa dan Bernegara, sekaligus silaturahmi. Di rayakan pada 18 
Agustus 2019 pukul 20.00-

03.00WIB lokasi Tepi Jalan Kp.Cilame II

c. Penerangan Jalanan Umum, Lampu jalan atau dikenal juga sebagai Penerangan Jalan Umum (PJU) adalah lampu yang digunakan untuk penerangan jalan dimalam hari sehingga mempermudah pejalan kaki, pesepeda dan pengendara kendaraan dapat melihat dengan lebih jelas jalan/medan yang akan dilalui pada malam hari, sehingga dapat meningkatkan keselamatan lalu lintas dan keamanan dari para pengguna jalan dari kegiatan/aksi kriminal. Clarke mengatakan bahwa better lighting will deter offenders who benefit from the cover of darkness atau dalam bahasa Indonesia: penerangan (jalan) yang lebih baik akan menghalangi penyerang yang mengambil manfaat dari kegelapan malam.Wilayah Pabangbon terkenal dengan adanya pariwisata, namun minimnya penerangan jalan setempat tidak memadai, dengan kondisi wilayah pohon yang menjuntai kurangnya penerangan pun menjadi hambatan penglihatan, maka dari itu kelompok ini menggagas adanya penerangan Jalan Umum Berbasis Tenaga Surya dan Listrik, dengan 10 titik yang terpasang 4 titik menggunakan tenaga surya dan 6 titik memanfaatkan listrik di mulai pada minggu ke 2 hingga selesai.

\section{Program Kerja Hukum}

a. Penyuluhan Hukum mengenai Surat Kepemilikan Tanah dan Pencatatan Perkawinan, Tujuan dan manfaat dilaksanakannya kegiatan ini adalah untuk memberikan pemahaman yang mendalam tentang pentingnya hukum dalam kehidupan khususnya mengenai hukum perkawinan dan hukum tanah dalam aspek perdata maupun pidana yang mengacu pada Undang-Undang yang berlaku yaitu KUHPerdata, KUHPidana, dan UU No 1 Tahun 1974 Tentang Perkawinan. Kegiatan ini dilaksanakan pada 28 Agustus 2019 jam 09.00-11.30 WIB yang dilaksanakan di Kantor Kecamatan Lewiliang, kegiatan ini pun diikuti oleh masyarakat se-Kecamatan dan para masyarakat Desa Pabangbon. Hasil dari dilaksanakannya kegiatan ini masyarakat Desa Pabangbon dapat memahami pentingnya hukum dalam kehidupan khususnya mengenai hukum perkawinan dan hukum tanah dalam aspek perdata dan aspek pidana sebagaimana undang-undang yang berlaku.

\section{Program Kerja Sosial Masyarakat}

a. Pembangunan Gapura Masjid, Bentuk kenang-kenangan terhadap warga kampung cilame II maka dari itu mencetuskan gapura permanen dengan konsep semimodern yang di buat permanen menggunakan beberapa material bangunan, dengan tujuan mempercantik pemandangan masjid agar masyarakat ingin senantiasa menginjak/berbondong bondong berdatangan ke masjid dengan keindahannya, proses pembuatan di mulai pada 13 Agustus 2019 sampai selesai di depan Masjid At Taqwa

b. Upacara sekaligus Merayakan 17 Agustus di Desa Pabangbon Adapun tujuan diadakannya kegiatan tersebut 
1. Untuk mengenang jasa para pahlawan

2. Merayakan Kemerdekaan RI

3. Meningkatkan Kebersamaan serta persatuan

4. Meningkatkan rasa cinta kepada tanah air

5. Memicu semangat dan keaktivan Yang diselenggarakan pada 17 Agustus di lapangan desa Pabangbon pukul 08.00WIB-Selesai

c. Merayakan 17 Agustus Se-kampung Cilame II RW 07

Menjadi pemicu atau gagasan terhadap pemuda setempat afar dapat bergerak membangun rasa satu kesatuan yang utuh terutama mengenang para pahlawan yang telah gugur sekaligus mempererat tali silaturahmi antar Kp. Cilame II dengan berkumpulnya disatu titik dan di adakan perlombaan tumpeng serta

\section{KESIMPULAN}

Berdasarkan hasil kegiatan, pengamatan, maupun pelaksanaan program kerja KKN yang telah direncanakan, disusun dan dilaksanakan. Maka kelompok $15 \quad \& \quad 16 \quad$ KKN UNIVERSITAS IBN KHALDUN BOGOR 2019 di Desa Pabangbon Kecamatan Leuwiliang mengambil beberapa kesimpulan yaitu :

- Keberhasilan KKN tidak lepas dari kerja sama antara mahasiswa dengan perangkat Desa, Masyarakat, serta semua pihak yang membantu dan mendukung terlaksananya kegiatan KKN tanpa adanya kerja sama yang baik, program kerja KKN tidak akan berjalan dengan lancar.

- Dengan adanya mahasiswa KKN masyarakat terbantu dengan dimakan bersama menambah rasa keharmonisan masyarakat menyatu. Kegiatan di laksanakan tanggal 18 Agustus 2019 pukul 08.00WIB Selesai di Lapangan Kp. Cilame II RW 07

d. Bakti Sosial, Dengan rasa mengetuk hati melihat beberapa kondisi masyarakat sekitar yang kurang, timbul lah program kerja yang insya allah senantiasa berguna bagi masyarakat, dengan menggunakan open donasi baik uang maupun barang alhamdulillah terkumpul beberapa pakaian layak guna dan materi sehingga acara bakti sosial menjadi kenangan terindah melihat mereka (warga) dapat tersenyum lebar walau tidak seberapa. Waktu pelaksanaan pada 1 September 2019 pukul 09.00- Selesai di Halaman Posko KKN

bertambahnya informasi dani lmu pengetahuan yang mereka peroleh dari mahasiswa KKN.

- Kurangnya kepedulian masyarakat desa terhadap lingkungan sekitar

- Potensi desa di Desa Pabangbon telah dikelola cukup baik oleh masyarakat, sehingga tercapai hasil yang cukup memuaskan, diantaranya:

a. Kerjasama yang baik antara masyarakat, perangkat desa serta instansi terkait guna memperlancar pembangunan desa.

b. Keterbukaan aparat desa terhadap masyarakat, mampu menjalin hubungan komunikasi yang baik. 
Dengan demikian, hasil kesimpulan di atas menunjukan bahwa secara garis besar program KKN kelompok 15 \& 16 dapat dikatakan sukses dan lancar meskipun ada beberapa kendala baik dari pihak mahasiswa maupun pihak masyarakat di Desa Pabangbon namun itu tidak berpengaruh terhadap program yang telah direncanakan.

\section{Dampak Bagi Masyarakat}

Dalam program-program kerja yang akan laksanakan dampak yang dapat diperoleh masyarakat antara lain :

1. Aspek Pendidikan

a. Bimbingan Belajar Manfaat penyelenggaraan bimbingan belajar ini adalah anak-anak dapat termotivasi untuk melanjutkan pendidikanya kejenjang yang lebih tinggi, juga membantu anak-anak mendapatkan ilmu yang lebih selain di sekolah. Membantu anak dalam mengerjakan PR. Anak-anak juga mendapat metode dan system pengajaran yang berbeda dengan di sekolah. Selain itu anakanak dapat meningkatkan kemampuan dalam menghaapi kesulitan dalam memahami pelajaran.

b. Pengajian Anak-anak Manfaat yang diperoleh yaitu agar pendidikan agama khususnya cara membaca al-quran yang baik dan benar dengan mengetahui hukum tajwidnya kepada anak-anak di lingkungan.

c. Pengajian ibu-ibu dan Bapak- Bapak Manfaat yang diperoleh yaitu agar Mempererat tali silaturahmi antar warga.

2. Aspek Kesehatan

a. PHBS Cuci Tangan Kegiatan ini dapat bermanfaat untuk ilmu pengetahuan yang baru untuk anak-anak dna ibuibu, bagaimana pentingnya mendidik anak untuk selalu mencuci tangan. b. Membantu Posyandu Kegiatan ini bermanfaat untuk mahasiswa itu sendiri karena ilmu yang telah di dapat dalam perkuliahan bisa di aplikasikan disana, seperti: Mengecek Tensi, Menimbang Bayi.

c. Senam Sehat Kegiatan senam sehat bermanfaat untuk menambah kebugaran warga-warga di desa Pabangbon.

d. Simulasi Evakuasi Gempa BumiBermanfaat agar para masyarakatdi desa Pabangbon bisa mengetahui tindakantindakanpengamanan diri jika terjadigempa bumi.

3. Aspek Ekonomi.

a. Gerakan Menabung Sejak Dini bertujuan agar para anak-anak di desa Pabangbon memiliki kebiasaan menabung sejak dini.

b. Pelatihan Kewirausahaan bertujuan agar masyarakat khususnya ibu-ibu di desa Cilame II bisa memanfaatkan apa yang ada di sekitar mereka untuk dijadikan sebagai usaha dan mata pencaharian.

4. Aspek Hukum

a. Penyuluhan Hukum mengenai Surat Kepemilikan Tanah dan Pencatatan Perkawinan. Penyuluhan ini bertujuan agar masayarakat mengetahui tentang hukum dalam hidup terutama hukum dalam perkawinan dan hukum tanah dalam aspek perdata maupun pidana

5. Aspek Lingkungan

a. Gotong royong Bertujuan untuk menjalin rasa kekeluargaan antar warga sekitar.

b. Perbaikan MCK Mesjid At-taqwa Kegiatan ini bertujuan memberikan kenyamanan kepada jamaah dan warga ketika menggunakan sarana MCK tersebut. 
6. Aspek Infrastruktur.

a. Pemasangan Lampu tenaga surya dan LED Bertujuan untuk membantu masyarakat sekitar kampung Cilame II dalam hal keamanan dan juga untuk menunjang aktivitas warga.

\section{REFERENSI}

Administrasi Profil Desa Pabangbon

LPPM: Universitas Ibn Khaldun Bogor (2019), Petunjuk Pelaksanaan Terintegrasi 2019

Rulhendi (2018), Memberdayakan Masyarakat Peduli, Cerdas dan Bersosial, Sehingga mampu bersaing Di Era Globalisasi di Desa Leuwimekar Sukamulya, Jurnal Abdi Dosen

Zulfa Hanum Alfi (2016), Membentuk Madrasah Diniyah Sebagai Alternatif Pendidikan Elite Muslim b. Pemasangan Gapura Mesjid At-taqwa dibuat sebagai bentuk kenagkenangan, permintaan masyarakat, Pabangbon, dibuat sejak minggu ke-2 hingga minggu ke-4.dan juga sebagai salah satu pembatas kampung yang ada di desa Pabangbon.

Bagi Masyarakat, Intizar, Vol. 22, No. 2, 2016

http://uchinfamiliar.blogspot.com/2009/0 2/tujuan-kedudukan-fungsi-majelistaklim.html

http://huzaifah7property.blogspot.com/20 17/02/kelebihan-manfaat-ratib-al$\underline{\text { hadad.html }}$

https://pendidikan.co.id/pengertianmenabung-macam-tujuan-danmanfaat/

https://id.wikibooks.org/wiki/Rekayasa_L alu_Lintas/Penerangan_jalan 